\title{
Development of New Rendemen Formula as an Effort to Control the Performance of Sugar Factory
}

\author{
Bambang Eddy Santoso ${ }^{1}$, Toto Martoyo ${ }^{1}$, dan Subhanuel Bahri ${ }^{1}$
}

\begin{abstract}
Based on the data of sugar factory performance in Java during 1936-1940 and 1956-2000 milling season periods, there are three important factors that can control contribution of each sector at sugar factory and absolutely affect targeted rendemen. Those factors include cane pol in the field, harvesting efficiency and factory efficiency. Cane pol in the field is a result of plantation sector performance. Harvesting efficiency represents the performance of harvesting sector, while factory efficiency has relationship with the performance of factory itself. In this research, the standard of factory performance was the data of factory performance in the milling season from 1936 to 1940 and the factory performance tested was the data of factory performance in the 1956-2000 milling season period. The aim of this research was to obtain a formula of rendemen calculation that represents a performance of all production aspects at sugar factory. The formula used for rendemen calculation was Rendemen $(\%)=$ cane pol in the field $(\%) \mathrm{x}$ harvesting efficiency $(\%) \times$ factory efficiency $(\%) \times 10^{-4}$. By using this concept, it is expected that targeted rendemen can be achieved since this concept can control all stages of production using the standard of each production aspect.
\end{abstract}

Key word - Rendemen, Cane pol in the field, harvesting efficiency, factory efficiency.

\section{Pendahuluan}

$S^{\mathrm{e}}$ lama ini, rendemen dibatasi pada tebu yang telah berada di emplasemen pabrik dan efisiensi pabrik yang mengolah. Rendemen didekati dengan rumus: (a) Rendemen $=$ Nilai nira perahan pertama $($ NNPP $) \mathrm{x}$ Kadar nira tebu (KNT) x Efisiensi pabrik; (b) Rendemen $=$ pol tebu $\mathrm{x}$ efisiensi pabrik $[1,2,3]$. Kedua rumus ini menghasilkan angka rendemen yang sama. Rumus ini sangat tepat untuk penilaian rendemen nyata dari tebu yang telah berada di emplasemen pabrik, karena sistem bagi hasil rendemen didasarkan pada tebu yang sedang diolah tersebut. Sehingga apabila target produksi (khususnya rendemen) yang telah dicanangkan untuk pabrik gula tersebut tidak tercapai dikatakan bahwa penyebabnya adalah efisiensi pabrik yang rendah [4]. Isu ini tidak semuanya benar, mungkin karena kualitas tebu (NNPP x KNT : 100, atau pol tebu) ren-

Naskah diterima pada tanggal 29 Desember 2008, selesai revisi pada tanggal 4 Februari 2009

${ }^{1}$ Bambang E. Santoso, Toto Martoyo, Subhanuel Bahri adalah peneliti Pusat Penelitian Perkebunan Gula Indonesia, J1. Pahlawan no. 25 Pasuruan, INDONESIA

E-mail : bachtiaragus@gmail.com dah, mungkin juga karena efisiensi pabrik rendah, atau mungkin karena kedua-duanya rendah.

Rumus rendemen yang disebutkan pertama [rumus (a)], biasa digunakan oleh pabrik gula di Indonesia, yang diketengahkan oleh Winter dan Hommes [3]. Menurut penemunya, rumus ini untuk menilai komponen mana yang bermasalah, dapat dilihat pada angkaangka kualitas tebu (NNPP dan KNT) dan efisiensi pabrik. Angka-angka tersebut dibandingkan dengan angka standarnya masing-masing, akan diketahui komponen mana yang bermasalah sehingga perlu untuk ditingkatkan performanya $[5,6,7]$. Rumus rendemen kedua [rumus (b)], biasa digunakan di luar negeri $[8,9,10]$. Di Indonesia rumus rendemen kedua cukup dikenal dan digunakan pada kasus-kasus tertentu $[5,6,7]$. Rumus rendemen tersebut dapat menetapkan efisiensi gilingan jika tebu yang diperah berkadar sabut standar $(12,5 \%)$, dan efisiensi pengolahan jika bahan baku yang diolah berkemurnian standar (harkat kemurnian $=85 \%$ ). Oleh karena itu untuk menyimpulkan apakah efisiensi pabrik menjadi penyebab rendahnya rendemen perlu dikaji terlebih dahulu nilai hasil pemerahan gula (efisiensi gilingan) jika bahan baku yang diolah berkadar sabut $12,5 \%\left(\mathrm{HPG}_{12,5}\right.$ ata $\mathrm{RE}$, reduced extraction menurut Deer) dan efisiensi pengolahan jika bahan baku yang diolah berkemurnian $85 \%\left(\mathrm{BHR}_{85}\right.$ atau $\mathrm{RBHR}$, reduced boiling house recovery menurut Gundu Rao) [3,5,8,9].

Kenyataan di lapang, jika dirunut pergerakan tebu yang dimulai dari kebun (pemilihan varietas, budidaya dan kategori tanaman tebu), tebang dan mengangkut tebu ke emplasemen pabrik dan sampai dihasilkan GKP; maka segmen pengontrolan kurang lengkap jika kinerja di Sektor Tanaman yang dikaitkan dengan pemilihan varietas, budidaya dan kategori tanaman tebu serta tebang muat angkut (TMA) tersebut tidak dinilai efisiensinya. Padahal di Sektor Pabrik, pergerakan tebu yang cukup sempit rentangnya yaitu dari emplasemen pabrik sampai digiling menjadi nira mentah (efisiensi gilingan) dan pergerakan dari nira mentah sampai dihasilkan GKP (efisiensi pengolahan) masing-masing telah ditentukan efisiensinya dan telah dilaporkan selama ini dalam "Laporan Periode 15 Harian" pabrik gula [4]. Santoso dan Martoyo [11] telah melaporkan hasil penelitiannya bahwa total sugar as sucrose (TSAS) dalam tebu yang berada di emplasemen pabrik adalah pendekatan dari pol tebu di kebun pada saat tebu tersebut ditebang pada saat kemasakan optimal. Dari penenelitian ini dapat diambil manfaat untuk 
menetapkan efisiensi tebang angkut (= pol tebu di emplasemen : pol tebu di kebun x 100), yaitu salah satu kontrol kinerja di Sektor Tanaman yang berkaitan dengan TMA. Oleh karena itu sangatlah mungkin untuk menetapkan efisiensi tebang angkut untuk mengontrol kinerja di Sektor Tanaman yang berkaitan dengan TMA.

Pol tebu di kebun dan efisiensi tebang angkut yang merupakan representasi partisi dari pol tebu di emplasemen pabrik menjadi sangat perlu untuk dimasukkan ke dalam rumus "rendemen". Sehingga dengan demikian kuantitas GKP yang dihasilkan (rendemen) tidak hanya dikontrol melalui kualitas tebu di emplasemen pabrik dan efisiensi pabrik saja, akan tetapi secara menyeluruh dapat dikontrol melalui kualitas tebu di kebun (pol tebu di kebun), efisiensi tebang angkut dan efisiensi pabrik.

Tujuan dari penelitian ini adalah untuk memperoleh formula pengembangan rendemen yang merumuskan rendemen sebagai fungsi dari pol tebu di kebun, efisiensi tebang angkut dan efisiensi pabrik sebagai upaya untuk mengontrol kinerja di Sektor Tanaman dan Pabrik dalam pencapaian rendemen yang ditargetkan.

\section{METODOLOGI}

Bahan yang diteliti adalah data keragaan giling atau kinerja pabrik gula di Jawa pada kurun masa giling (KMG) lima tahunan pada kurun waktu 1936 - 1940 dan KMG 1956 - 2000 [12,13,14,15,16,17,18,19,20, 21].

Mengambil langsung data keragaan giling tentang pol tebu di emplasemen pabrik (PtE), pol tebu dalam nira mentah (PtNM) dan pol tebu dalam hasil (PtH).

Menghitung pol tebu di kebun pada saat tebu tersebut ditebang pada kemasakan optimal (PtK) [5,6,7,10, 22,23,24,25,26,27].

Menghitung efisiensi di masing-masing sektor. Efisiensi tebang angkut $(\mathrm{ETa})=\mathrm{PtE}: \mathrm{PtK} \times 100$, efisiensi gilingan $(\mathrm{EGi})=$ PtNM : PtE $\times 100$ dan efisiensi pengolahan $(\mathrm{EPe})=\mathrm{PtH}: \mathrm{PtNM} \times 100$. Efisiensi pabrik $(\mathrm{EPa})=\mathrm{EGi} \times \mathrm{EPe} \times 10^{-2}=\mathrm{PtH}: \mathrm{PtE} \times 100$.

Menghitung $\mathrm{HPG}_{12,5}=100-[\{(100-\mathrm{HPG}) \times(100$ - sabut tebu)\} : (7 x sabut tebu)] dan $\mathrm{BHR}_{85}=\mathrm{BHR}$ $+100 \times\{(1700-\mathrm{HK} \mathrm{nm}) \times$ Berat bukan gula nire encer $\times$ HK tetes $\}:\{(17 \times \mathrm{HK} \mathrm{nm}) \times$ Berat bukan gula nira mentah $\mathrm{x}(100-\mathrm{HK}$ tetes $)\}$.

Analisis statistik yang digunakan untuk mengevaluasi data tersebut adalah analisis variansi, perbandingan ganda dan analisis regresi [28,29]. Analisis variansi 2 arah (arah KMG dengan 10 aras dan arah Ulangan atau tahun giling pada KMG dengan 5 aras) terhadap data PtK, PtE, PtNM, PtH, ET, EG, EPe dan EPa untuk melihat tingkat signifikansi antar KMG. Perbandingan ganda untuk menetapkan rangking antar KMG untuk PtK, PtE, PtNM, PtH, ETa, EGi, EPe dan EPa. Analisis regresi sederhana dilakukan untuk melihat trend pada 5 tahun giling setiap KMG. Analisis regresi ganda dilakukan untuk melihat korelasi dan kontribusi PtK, ETa, EGi dan EPe terhadap rendemen.

\section{HaSil dan Pembahasan}

Pol Tebu di Kebun (PtK). Pol tebu di kebun seluruh pabrik gula di Jawa pada KMG I - KMG X disajikan pada Tabel 1 .

TABEL 1

POL TEBU DI KEBUN (PTK) SELURUH PABRIK GULA DI JAWA PADA KMG I - KMG X

\begin{tabular}{lllll}
\hline \multicolumn{2}{l}{ KMG } & \multicolumn{3}{c}{ Pol tebu di Kebun } \\
& & PtK, \% & Trend $(0,-,+)$ \\
\hline I & $(1936-1940)$ & 14,28 & (a) & 0 \\
II & $(1956-1960)$ & 14,04 & (a) & 0 \\
III & $(1961-1965)$ & 13,59 & (b) & 0 \\
IV & $(1966-1970)$ & 12,99 & (c) & 0 \\
V & $(1971-1975)$ & 13,50 & (b) & 0 \\
VI & $(1976-1980)$ & 12,77 & (c) & 0 \\
VII & $(1981-1985)$ & 11,58 & (d) & 0 \\
VIII & $(1986-1990)$ & 11,30 & (e) & 0 \\
IX & $(1991-1995)$ & 11,21 & (e) & 0 \\
X & $(1996-2000)$ & 10,05 & (f) & 0 \\
\hline
\end{tabular}

KMG = Kurun Masa Giling 5 tahunan; PtK: Pol Tebu di Kebun; Angka yang diikuti oleh huruf yang sama pada kolom yang sama menunjukkan tidak berbeda nyata (Newman Keuls, taraf 5\%); Trend: tanda (0) menunjukkan tidak terdapat trend turun atau naik dalam KMG, tanda (-) menunjukkan terdapat trend turun dalam $\mathrm{KMG}$, trend (+) menunjukkan terdapat trend naik dalam KMG.

Pol tebu di kebun (PtK) pada KMG I (14,28 \%) tidak berbeda dengan KMG II (14,04\%). Pol tebu di kebun kedua KMG tersebut berbeda dengan pol tebu di kebun dengan KMG-KMG lainnya (10,05 - 13,59 \%). Selisih PtK pada KMG I dan KMG II dengan PtK pada KMG lainnya sekitar $0,45-4,23$ poin. Hal ini menunjukkan potensi pol tebu di masa sebelum 1960an lebih baik dibanding setelah 1960-an, atau pemilihan varietas dan pengelolaan budidaya tebu terkendali dan terpadu. Setelah KMG III $(13,59 \%)$ mulai menurun, kemudian mulai ada peningkatan lagi pada KMG V (13,50\%), dan setelah itu menurun secara tajam, paling rendah pada KMG X (10,05\%), Tabel 1. Pada Tabel 1 terlihat pula bahwa PtK setiap KMG tidak terdapat trend turun atau naik.

Pol Tebu di Emplassemen (PtE). Pol tebu di emplasemen seluruh pabrik gula di Jawa pada KMG I - KMG X disajikan pada Tabel 2.

Pol tebu di emplasemen (PtE) pada KMG I (13,51 $\%)$ tertinggi dibanding PtE pada KMG lainnya (8,77 $13,19 \%)$. Selisih PtE pada KMG I dengan PtE pada KMG lainnya sekitar $0,32-4,74$ poin. Hal ini menunjukkan di samping potensi pol tebu yang dikaitkan dengan pemilihan varietas dan pengelolaan budidaya, juga tebang muat angkut (TMA) di masa sebelum 1940an lebih baik dibanding setelah 1940-an. Artinya, pemilihan varietas, pengelolaan budidaya tebu dan TMA terkendali dan terpadu dengan kecepatan giling sehingga PtE masih tinggi (hanya berbeda 0,77 poin dari potensinya). Setelah KMG II $(13,19 \%)$ mulai menu- 
run, kemudian mulai ada peningkatan lagi pada KMG $\mathrm{V}(12,53 \%)$. Namun, setelah itu menurun secara tajam, pada KMG X paling rendah $(8,77 \%)$ dan berbeda 1,28 poin dari potensinya (PtK), Tabel 2. Pada Tabel 2 terlihat pula bahwa PtE setiap KMG tidak terdapat trend turun atau naik.

TABEL 2

POL TEBU DI EMPLASSEMEN (PTE) SELURUH PABRIK GULA DI JAWA PADA KMG I DAN KMG II - KMG X

\begin{tabular}{lcrll}
\hline \multirow{2}{*}{ KMG } & \multicolumn{3}{c}{ Pol tebu di Emplasemen } \\
\cline { 3 - 5 } & & PtE, \% & Trend $(0,-,+)$ \\
\hline I & $(1936-1940)$ & 13,51 & (a) & 0 \\
II & $(1956-1960)$ & 13,19 & (b) & 0 \\
III & $(1961-1965)$ & 12,52 & (c) & 0 \\
IV & $(1966-1970)$ & 11,92 & (d) & 0 \\
V & $(1971-1975)$ & 12,53 & (c) & 0 \\
VI & $(1976-1980)$ & 11,82 & (d) & 0 \\
VII & $(1981-1985)$ & 10,50 & (e) & 0 \\
VIII & $(1986-1990)$ & 10,16 & (f) & 0 \\
IX & $(1991-1995)$ & 9,84 & (g) & 0 \\
X & $(1996-2000)$ & 8,77 & (h) & 0 \\
\hline
\end{tabular}

KMG: Kurun Masa Giling 5 tahunan; PtE: Pol Tebu di Emplassemen; Angka yang diikuti oleh huruf yang sama pada kolom yang sama menunjukkan tidak berbeda (Newman Keuls, taraf 5\%); Trend : tanda (0) menunjukkan tidak terdapat trend turun atau naik dalam KMG, tanda (-) menunjukkan terdapat trend turun dalam KMG, tanda (+) menunjukkan terdapat trend naik dalam KMG.

Pol Tebu di Nira Mentah (PtM). Pol tebu di nira mentah seluruh pabrik gula di Jawa pada KMG I KMG X disajikan pada Tabel 3.

TABEL 3

POL TEBU DI NIRA MENTAH SELURUH PABRIK GULA DI JAWA KMG I DAN KMG II - KMG X

\begin{tabular}{lcrrr}
\hline \multirow{2}{*}{ KMG } & \multicolumn{3}{c}{ Pol tebu di Nira Mentah } \\
\cline { 3 - 5 } & & \multicolumn{2}{c}{ PtNM, \% } & Trend $(0,-,+)$ \\
\hline I & $(1936-1940)$ & 12,78 & (a) & 0 \\
II & $(1956-1960)$ & 12,18 & (b) & 0 \\
III & $(1961-1965)$ & 11,47 & (c) & 0 \\
IV & $(1966-1970)$ & 10,87 & (d) & 0 \\
V & $(1971-1975)$ & 11,52 & (c) & 0 \\
VI & $(1976-1980)$ & 10,89 & (d) & 0 \\
VII & $(1981-1985)$ & 9,60 & (e) & 0 \\
VIII & $(1986-1990)$ & 9,36 & (f) & 0 \\
IX & $(1991-1995)$ & 9,04 & (g) & 0 \\
X & $(1996-2000)$ & 7,99 & (h) & 0 \\
\hline
\end{tabular}

KMG : Kurun Masa Giling 5 tahunan, PtNM : Pol Tebu di Nirah Mentah; Angka yang diikuti oleh huruf yang sama pada kolom yang sama menunjukkkan tidak berbeda (Newman Keuls, taraf 5\%); Trend : tanda (0) menunnjukkan tidak terdapat trend turun atau naik dalam KMG, tanda (-) menunjukkan terdapat trend turun dalam KMG, tanda (+) menunjukkan terdapat trend naik dalam KMG.
Pol tebu di nira mentah (PtNM) atau pol nira mentah \% tebu pada KMG I (12,78\%) tertinggi dibanding PtNM pada KMG lainnya (7,99 - 12,18\%). Selisih PtNM pada KMG I dengan PtK pada KMG-KMG lainnya sekitar $0,60-4,79$ poin. Hal ini menunjukkan potensi pol tebu dan TMA di masa sebelum 1940-an lebih baik dibanding setelah 1940-an sehingga ekstraksi pol (pemerahan gula) di gilingan tertinggi. Setelah KMG II (12,18 \%) mulai menurun, kemudian mulai ada peningkatan lagi pada KMG V (11,52\%). Setelah itu menurun secara tajam, pada KMG X paling rendah $(7,99 \%)$ dan berbeda 0,78 poin dari PtE, Tabel 3. Pada Tabel 3 terlihat pula bahwa PtNM setiap KMG tidak terdapat trend turun atau naik.

Pol Tebu di Nirah Hasil (PtH). Pol tebu di nira mentah seluruh pabrik gula di Jawa pada KMG I KMG X disajikan pada Tabel 4.

Pol tebu di Hasil (PtH) pada KMG I (11,97 \%) tertinggi dibanding PtH pada KMG lainnya (6,71 s/d $11,09 \%)$. Selisih PtH pada KMG I dengan PtH pada KMG lainnya sekitar $0,88-4,26$ poin. Hal ini menunjukkan potensi pol tebu dan TMA di masa sebelum 1940-an lebih baik dibanding setelah 1940-an sehingga mengolah tebu dengan kualitas yang demikian untuk menjadi kristal lebih mudah dan lancar. Setelah KMG I (11,09 \%) mulai menurun, kemudian mulai ada peningkatan lagi pada KMG V (10,29\%), dan setelah itu menurun secara tajam. Pada KMG X paling rendah $(6,71 \%)$ dan berbeda 1,28 poin dari $\mathrm{PtNM}$, Tabel 4. Pada Tabel 4 terlihat pula bahwa PtH setiap KMG tidak terdapat trend turun atau naik.

TABEL 4

POL TEBU DI HASIL (PTH) DI SELURUH PABRIK GULA DI JAWA PADA KMG I DAN KMG II - KMG X

\begin{tabular}{lcrcc}
\hline \multirow{2}{*}{ KMG } & \multicolumn{2}{c}{ Pol tebu di Hasil } \\
\cline { 3 - 5 } & & \multicolumn{1}{c}{ PtH, \% } & Trend $(0,-,+)$ \\
\hline I & $(1936-1940)$ & 11,97 & (a) & 0 \\
II & $(1956-1960)$ & 11,09 & (b) & 0 \\
III & $(1961-1965)$ & 10,19 & (c) & 0 \\
IV & $(1966-1970)$ & 9,59 & (d) & 0 \\
V & $(1971-1975)$ & 10,29 & (c) & 0 \\
VI & $(1976-1980)$ & 9,71 & (d) & 0 \\
VII & $(1981-1985)$ & 8,39 & (e) & 0 \\
VIII & $(1986-1990)$ & 8,16 & (e) & 0 \\
IX & $(1991-1995)$ & 7,81 & (f) & 0 \\
X & $(1996-2000)$ & 6,71 & (g) & 0
\end{tabular}

KMG : Kurun Masa Giling 5 tahunan; PtH : Pol Tebu di Hasil (rendemen); Angka yang diikuti oleh huruf yang sama pada kolom yang sama menunjukkan tidak berbeda (Newman Keuls: taraf 5\%); Trend : tanda (0) menunjukkan tidak terdapat trend turun atau naik dalam KMG, tanda (-) menunjukkan ada trend turun dalam KMG, tanda (+) menunjukkan ada trend naik dalam KMG. 
Tebang Angkut. Dari Tabel 1 dan 2 dihitung efisiensi tebang angkut $(\mathrm{ETa})$, yaitu ETa $=$ PtE $:$ PtK $x$ 100. Hasilnya disajikan pada Tabel 5.

Efisiensi tebang angkut (ETa) pada KMG I (94,63 $\%$ ) berbeda dan lebih tinggi dari efisiensi tebang angkut pada KMG lainnya (87,20 s/d 93,96 \%). Selisih ETa pada KMG I dengan KMG lainnya sekitar 0,67 7,43 poin. Hal ini menunjukkan bahwa tebang angkut sebagai upaya untuk penyelamatan gula di dalam batang tebu dari kebun sampai ke emplasemen pabrik pada KMG I lebih baik dibanding KMG lainnya, setelah KMG I semakin menurun. Terlihat mulai menurun setelah KMG VI, setelah itu menurun secara tajam dan yang paling rendah pada KMG X. Dalam internal KMG I efisiensi tebang angkut ada trend naik, sebaliknya dalam internal KMG VI efisiensi tebang angkut ada trend turun, Tabel 5.

TABEL 5

EFISIENSI TEBANG ANGKUT (ETA) DI SELURUH PABRIK GULA DI JAWA KMG I DAN KMG II - KMG X

\begin{tabular}{|c|c|c|c|}
\hline & \multirow{2}{*}{$\mathrm{KMG}$} & \multicolumn{2}{|c|}{ Tebang angkut } \\
\hline & & $\mathrm{ETa}, \%$ & Trend $(0,-,+)$ \\
\hline I & $(1936-1940)$ & 94,63 (a) & + \\
\hline II & (1956-1960) & 93,96 (b) & 0 \\
\hline III & $(1961-1965)$ & 92,08 (d) & 0 \\
\hline IV & (1966-1970) & 91,77 (d) & 0 \\
\hline V & (1971-1975) & 92,78 (c) & 0 \\
\hline VI & (1976-1980) & $92,51(\mathrm{~cd})$ & - \\
\hline VII & $(1981-1985)$ & 90,60 (e) & 0 \\
\hline VII & I (1986-1990) & 89,90 (f) & 0 \\
\hline IX & (1991-1995) & $87,81 \quad(\mathrm{~g})$ & 0 \\
\hline $\mathrm{X}$ & (1996-2000) & $87,20 \quad(h)$ & 0 \\
\hline
\end{tabular}

KMG : Kurun Masa Giling 5 tahunan; Eta : Efisiensi Tebang Angkut; Angka yang diikuti oleh huruf yang sama pada kolom yang sama menunjukkan tidak berbeda (Newman Keuls, taraf 58\%); Trend : tanda (0) menunjukkan tidak ada trend turun atau naik dalam KMG, tanda (-) menunjukkan terdapat trend turun dalam KMG, tanda (+) menunjukkan terdapat trend naik dalam KMG.

Menurunnya kedua indikator mendasar untuk mengontrol kinerja tanaman (pol tebu di kebun dan efisiensi tebang angkut) dari KMG ke KMG diduga disebabkan oleh pengelolaan tebu yang berbeda, pada KMG I sampai dengan KMG V tebu dikelola sendiri oleh Bagian Tanaman pabrik gula sehingga pemilihan varietas, pengelolaan budidaya, tebang angkut dan kecepatan giling dapat ditangani dengan terkendali dan terpadu. Sedangkan pada KMG VI sampai dengan. KMG X tebu dikelola oleh petani tebu rakyat (PTR) sehingga pemilihan varietas, pengelolaan budidaya, TMA dan kecepatan giling tidak atau kurang terkendali dan terpadu.

Stasiun Gilingan. Berdasarkan Tabel 2 dan 3, dihitung efisiensi gilingan (EGi) yaitu dengan rumus: EGi $=$ PtNM : PtE x 100. Hasilnya disajikan pada Tabel 6 .

Efisiensi gilingan (EGi) pada KMG I $(94,57 \%)$ tertinggi dibanding EGi pada KMG lainnya $(90,99$ s/d
92,35 \%). Selisih EGi pada KMG I dengan EGi pada KMG lainnya sekitar 2,22 - 3,58 poin. Hal ini menunjukkan pemerahan gula yang dihasilkan di stasiun gilingan sebagai upaya untuk penyelamatan gula dalam batang tebu di emplasemen pada KMG I lebih baik dibanding pada KMG lainnya, setelah itu semakin menurun. Terlihat mulai menurun setelah KMG VIII, dan yang paling rendah pada KMG X. Di dalam intern KMG II terlihat ada trend penurunan EGi, namun demikian EGi rata-rata KMG masih tinggi (92,35 \%), Tabel 6.

TABEL 6

EFISIENSI GILINGAN (EGI) SELURUH PABRIK GULA DI JAWA PADA KMG I DAN KMG II - KMG X

\begin{tabular}{|c|c|c|c|}
\hline \multirow{2}{*}{\multicolumn{2}{|c|}{ KMG }} & \multicolumn{2}{|c|}{ Stasiun Gilingan } \\
\hline & & $\mathrm{EGi}, \%$ & Trend $(0,-,+)$ \\
\hline I & (1936-1940) & 94,57 (a) & 0 \\
\hline II & (1956-1960) & 92,35 (b) & - \\
\hline III & (1961-1965) & $91,62(\mathrm{~cd})$ & 0 \\
\hline IV & $(1966-1970)$ & 91,13 (de) & 0 \\
\hline $\mathrm{V}$ & $(1971-1975)$ & 91,95 (c) & 0 \\
\hline VI & $(1976-1980)$ & $92,11 \quad(\mathrm{bc})$ & 0 \\
\hline VII & $(1981-1985)$ & $91,33(d)$ & 0 \\
\hline VII & I (1986-1990) & $92,13(\mathrm{bc})$ & 0 \\
\hline IX & (1991-1995) & $91,83(\mathrm{~cd})$ & 0 \\
\hline $\mathrm{X}$ & (1996-2000) & 90,99 (e) & 0 \\
\hline
\end{tabular}

KMG : Kurun Masa Giling 5 tahunan; EGi : Efisiensi Gilingan; Angka yang diikuti oleh huruf yang sama pada kolom yang sama menunjukkan tidak berbeda (Newman Keuls : taraf 5\%); Trend : tanda (0) menunjukkan tidak terdapat trend turun atau naik dalam KMG, tanda (-) menunjukkan terdapat trend turun dalam KMG, tanda (+) menunjukkan terdapat trend naik dalam KMG.

Stasiun Pengolahan. Dari Tabel 3 dan 4 dihitung efisiensi pengolahan $(\mathrm{EPe})$, yaitu $\mathrm{EPe}=\mathrm{PtH}: \mathrm{PtNM} \mathrm{x}$ 100. Hasilnya disajikan pada Tabel 7.

Efisiensi pengolahan (EPe) pada KMG I (93,63\%) tertinggi dibanding EPe pada KMG lainnya (83,80 s/d 91,02 \%). Selisih EPe pada KMG I dengan KMG lainnya sekitar 2,61 - 9,83 poin. Hal ini menunjukkan pemerahan kristal sebagai upaya untuk penyelamatan kristal dari gula di dalam nira mentah sampai ke stasiun penyelesaian pada KMG I lebih baik dibanding KMG lainnya, setelah itu semakin menurun. Terlihat mulai menurun setelah KMG VI, dan yang paling merosot pada KMG X. Seperti halnya dengan ETa, pada intern KMG I ada trend naik, sedangkan dalam intern KMG VI ada trend turun, Tabel 2.

Selanjutnya, dari Tabel 6 dan 7 dihitung efisiensi pabrik $(\mathrm{EPa})$, yaitu dengan rumus: $\mathrm{EPa}=\mathrm{EGi} \times \mathrm{EPe}$ : 100. Hasilnya disajikan pada Tabel 8.

Efisiensi pabrik (EPa) adalah resultan dari efisiensi gilingan dan pengolahan, pada KMG I $(88,54 \%)$ lebih tinggi dibandingkan KMG lainnya (76,26 - 84,06 \%). Selisih EPa pada KMG I dengan KMG lainnya sekitar $4,48-12,28$ poin. Hal ini berarti secara umum efisiensi pabrik sebagai upaya untuk penyelamatan kristal tebu di emplasemen sampai ke produk yang dikarungi 
dari KMG ke KMG semakin menurun. Terlihat mulai menurun setelah KMG VI, dan yang paling rendah pada KMG X. Hal ini diduga disebabkan oleh kualitas tebu yang diolah (pol tebu di emplasemen) semakin menurun. Seperti halnya dengan ETa dan EPe, pada intern KMG I ada trend naik, sedangkan dalam intern KMG VI ada trend turun. Tampaknya ada keterkaitan antara EPa dengan ETa, trend naik ETa diikuti trend naik EPe, begitu pula sebaliknya, Tabel 2.

TABEL 7

EFISIENSI PENGOLAHAN SELURUH PABRIK GULA DI JAWA KMG I DAN KMG II - KMG X

\begin{tabular}{llll}
\hline & \multirow{2}{*}{ KMG } & \multicolumn{2}{c}{ Stasiun Pengolahan } \\
\cline { 3 - 4 } & & EPe, \% & Trend $(0,-,+)$ \\
\hline I & $(1936-1940)$ & $93,63 \mathrm{a}$ & + \\
II & $(1956-1960)$ & $91,02 \mathrm{~b}$ & 0 \\
III & $(1961-1965)$ & $88,87 \mathrm{~d}$ & 0 \\
IV & $(1966-1970)$ & $88,20 \mathrm{e}$ & 0 \\
V & $(1971-1975)$ & $89,30 \mathrm{c}$ & 0 \\
VI & $(1976-1980)$ & $89,13 \mathrm{c}$ & - \\
VII & $(1981-1985)$ & $87,39 \mathrm{f}$ & 0 \\
VIII (1986-1990) & $87,24 \mathrm{f}$ & 0 \\
IX & $(1991-1995)$ & $86,34 \mathrm{~g}$ & 0 \\
X & $(1996-2000)$ & $83,80 \mathrm{~h}$ & 0 \\
\hline
\end{tabular}

KMG : Kurun Masa Giling 5 tahunan; EPe : Efisiensi Pengolahan; Angka pada kolom yang sama menunjukkan tidak berbeda (Newman Keuls, taraf 5\%); Trend : tanda (0) menunjukkan tidak terdapat trend turun atau naik dalam KMG, tanda (-) manunjukkan terdapat trend turun dalam $\mathrm{KMG}$, tanda $(+)$ menunjukkan terdapat trend naik dalam KMG.

TABEL 8

EFISIENSI PABRIK SELURUH PABRIK GULA DI JAWA KMG I DAN KMG II - KMG X

\begin{tabular}{lccc}
\hline \multirow{4}{*}{ KMG } & \multicolumn{2}{c}{ Efisensi Pabrik } \\
\cline { 3 - 4 } & & EPa, \% & Trend $(0,-,+)$ \\
\hline I & $(1936-1940)$ & $88,54 \mathrm{a}$ & + \\
II & $(1956-1960)$ & $84,06 \mathrm{~b}$ & 0 \\
III & $(1961-1965)$ & $81,42 \mathrm{~d}$ & 0 \\
IV & $(1966-1970)$ & $80,38 \mathrm{e}$ & 0 \\
V & $(1971-1975)$ & $82,11 \mathrm{c}$ & 0 \\
VI & $(1976-1980)$ & $82,09 \mathrm{c}$ & - \\
VII & $(1981-1985)$ & $79,82 \mathrm{f}$ & 0 \\
VIII & $(1986-1990)$ & $80,37 \mathrm{e}$ & 0 \\
IX & $(1991-1995)$ & $79,29 \mathrm{~g}$ & 0 \\
X & $(1996-2000)$ & $76,26 \mathrm{~h}$ & 0 \\
\hline
\end{tabular}

KMG :Kurun Masa Giling 5 tahunan; EPa : Efisiensi Pabrik; Angka yang diikuti oleh huruf yang sama pada kolom yang sama menunjukkan tidak berbeda (Newman Keuls, taraf 5\%); Trend : tanda (0) menunjukkan tidak terdapat trend turun atau naik dalam KMG, tanda (-) menunjukkan terdapat trend turun dalam KMG, tanda (+) menunjukkan terdapat trend naik dalam KMG.

Efisiensi Pabrik Direduksi. Efisiensi pabrik direduksi artinya efisiensi pabrik jika tebu yang diolah mempunyai kualitas normal, yaitu kadar sabut tebu $12,5 \%$ dan kemurnian (HK) nira mentah $85 \%$. Efisiensi gilingan pada kadar sabut $12,5 \%\left(\mathrm{EGi}_{12,5} ;\right)$, efisiensi pengolahan pada $\mathrm{HK}$ nira mentah yang diolah $85 \%\left(\mathrm{EPe}_{85}\right)$ dan efisiensi pabrik pada bahan baku normal $\left(\mathrm{EPa}_{12,5 ; 85}\right)$ di seluruh pabrik gula di Jawa KMG I dan KMG II - KMG X disajikan Pada Tabel 9.

Jika tebu yang diolah dikembalikan kepada keadaan bahan baku normal maka Efisiensi gilingan sesungguhnya $\left(\mathrm{EGi}_{12,5}\right)$ yang telah dicapai pada KMG I (94,95\%) tertinggi dibanding dengan KMG lainnya, sedangkan pada KMG II - KMG X sama, tidak begitu berbeda (sekitar $93 \%$ ). Efisiensi pengolahan sesungguhnya $\left(\mathrm{EPe}_{85}\right)$ yang telah dicapai pada KMG I $(92,04$ $\%)$ tertinggi dibanding dengan KMG lainnya, sedangkan pada KMG II - KMG X nyaris tidak berbeda (90 - $91 \%)$. Efisiensi pabrik sesungguhnya $\left(\mathrm{EPa}_{12,5 ; 85}\right)$ yang telah dicapai pada KMG I $(87,39 \%)$ tetap tertinggi dibanding KMG lainnya, sedangkan pada KMG II - KMG X tidak berbeda (sekitar $84 \%$ ).

Dari uraian di atas menunjukkan bahwa performance pabrik (gilingan dan pengolahan) dari pabrik gula di Jawa pada saat ini tidak kalah dengan performance pabrik dari pabrik gula di Jawa pada masa 1955-an jika pabrik gula tersebut mengolah tebu yang mempunyai kualitas sama dengan masa 1955-an. Oleh karena itu rendahnya rendemen selama ini tidak semata-mata disebabkan oleh efisiensi pabrik tetapi juga pol tebu di kebun dan efisiensi tebang angkut. Hal ini cukup logis karena pabrik yang merupakan bagian dari pabrik gula secara menyeluruh setiap tahun selalu melakukan pemeliharaan, perbaikan dan penggantian peralatan pabrik serta melakukan revitalisasi peralatan pabrik secara bertahap untuk meningkatkan kinerja di Sektor Pabrik. Dapat dikatakan bahwa peralatan pabrik saat ini lebih modern dibanding peralatan pabrik pada kurun masa 1955 - 1975.

Sebagai contoh terapan dari Tabel 1 - Tabel 9: Jika pol tebu di kebun (PtK) dan efisiensi tebang angkut (ETa) pada KMG X (1996 - 2000) sama dengan pada KMG II (1956 - 1960) yaitu PtK = 14,04 \% dan ETa $=93,96 \%$ (Tabel 1 dan Tabel 5). Jika efesiensi gilingan (EGi) dan efisiensi pengolahan (EPe) pada KMG X sama dengan $\mathrm{EGi}_{12,5}$ dan $\mathrm{EPe}_{85}$ pada KMG X yaitu $\mathrm{EGi}=93,05 \%$ dan $\mathrm{EPe}=91,18 \%$ (Tabel 9), maka rendemen yang dihasilkan $(\mathrm{PtH})$ pada KMG X = $14,04 \%$ x 93,96\% x 93,05\% x 91,18\%=11,19\%. Hasil ini tidak kalah dengan rendemen yang dihasilkan pada KMG II (11,09\%). Dalam hal ini artinya bahwa jika PtK dan ETa (atau PtE = PtK x ETa : 100) pada saat ini tinggi minimal sama dengan PtK dan ETa pada KMG II (1956 - 1960) maka rendemen yang dihasilkan minimal sama dengan $11,19 \%$. Oleh karena itu dalam pencapaian target rendemen diperlukan suatu formula pengembangan rendemen yang melibatkan semua sektor produksi secara menyeluruh yang dapat digunakan sebagai kontrol setiap tahapan produksi. 
TABEL 9

EFISIENSI PABRIK DIREDUKSI KE BAHAN BAKU NORMAL DI SELURUH PABRIK GULA DI JAWA PADA KMG I DAN KMG II - KMG X

\begin{tabular}{cccccccccc}
\hline \multirow{2}{*}{ KMG } & \multicolumn{9}{c}{ Pabrik } \\
\cline { 2 - 10 } & \multicolumn{1}{c}{$\mathrm{EGi}_{12,5}, \%$} & \multicolumn{3}{c}{$\mathrm{EPa}_{12,5 / 85}, \%$} \\
\hline I & 94,95 & (a) & 0 & 92,04 & (a) & 0 & 87,39 & (a) & 0 \\
II & 93,89 & (b) & - & 90,25 & (d) & 0 & 84,74 & (c) & - \\
III & 93,32 & (d) & 0 & 90,07 & (e) & - & 84,05 & (e) & 0 \\
IV & 93,03 & (e) & 0 & 89,78 & (f) & 0 & 83,52 & (f) & 0 \\
V & 93,23 & (de) & 0 & 90,09 & (e) & 0 & 84,00 & (e) & 0 \\
VI & 93,52 & (c) & 0 & 90,32 & (d) & 0 & 84,47 & (d) & 0 \\
VII & 93,13 & (de) & 0 & 90,37 & (d) & + & 84,16 & (e) & 0 \\
VIII & 93,72 & (bc) & 0 & 91,23 & (c) & 0 & 85,51 & (b) & 0 \\
IX & 93,58 & (bc) & 0 & 91,46 & (b) & 0 & 85,59 & (b) & 0 \\
X & 93,05 & (e) & 0 & 91,18 & (c) & - & 84,84 & (c) & - \\
\hline
\end{tabular}

KMG : kurun masa giling 5 tahunan; $\mathrm{EGi}_{12,5}=$ efisiensi gilingan direduksi pada kadar sabut tebu $12,5 \% ; \mathrm{EPe}_{85}=$ efisiensi pengolahan yang direduksi pada $\mathrm{HK}$ nira mentah $85 \% ; \mathrm{EPa}_{12,5 / 85}=$ efisiensi pabrik yang direduksi pada kadar sabut $12,5 \%$ dan $\mathrm{HK}$ nira mentah $85 \%$; Angka yang diikuti oleh huruf yang sama pada kolom yang sama menunjukkan tidak berbeda (Newman Keuls, taraf $5 \%$ ); Trend: tanda (0) menunjukkan tidak terdapat trend turun atau naik dalam KMG, tanda (-) menunjukkan terdapat trend turun dalam KMG, tanda $(+)=$ ada trend naik dalam $\mathrm{KMG}$

Formula Pengembangan Rendemen. Rendemen adalah kristal nyata yang dihasilkan setiap 100 satuan berat tebu. Rendemen $=$ pol tebu $\mathrm{x}$ efisiensi pabrik $\mathrm{x}$ $10^{-2}$. Pol tebu menyatakan akumulasi hasil kinerja di Sektor Tanaman, efisiensi pabrik menyatakan akumulasi hasil kinerja di Sektor Pabrik. Formula tersebut telah bersifat official, menyatakan fungsi dari pol tebu giling (pol tebu di emplasemen pabrik) dan efisiensi di Sektor Pabrik (Unit Gilingan dan Unit Pengolahan). Dalam formula tersebut tidak dapat mengetahui seberapa besar pol potensi (pol tebu di kebun) dan efisiensi tebang angkut di Sektor Tanaman. Untuk itu perlu ada suatu formula yang menjelaskan pol tebu di emplasemen pabrik tersebut menjadi pol tebu di kebun dan efisiensi tebang angkut sehingga menjadi informatif secara menyeluruh.

Berdasarkan hasil penelitian Santoso dan Martoyo [4] didapat pol tebu di kebun yang dapat didekati dengan TSAS tebu yang berada di emplasemen pabrik. Oleh karena itu dapat diambil manfaat bahwa efisiensi tebang angkut $=$ pol tebu di emplasemen pabrik : TSAS tebu di emplasemen pabrik x 100. Sampel yang diambil untuk mendapatkan TSAS tebu di emplasemen pabrik sama seperti untuk mendapatkan pol tebu di emplasemen pabrik. Sampling bahan tersebut sudah biasa dilakukan di pabrik gula. Pol tebu di emplasemen pabrik $=$ pol tebu dalam ampas + pol tebu dalam nira mentah, demikian juga untuk TSAS tebu di emplasemen pabrik.

Formula pengembangan rendemen yang merumuskan rendemen sebagai fungsi dari pol tebu di kebun, efisiensi tebang angkut dan efisiensi pabrik sebagai upaya untuk mengontrol kinerja di Sektor Tanaman dan Pabrik dalam pencapaian rendemen yang ditargetkan disajikan pada persamaan (1).

$[$ Rendemen $(\%)]=[$ Pol tebu di kebun $(\%) \times$ Efisiensi tebang angkut $(\%) \mathrm{x}$ Efisiensi pabrik (\%) $\mathrm{x}$ $10^{-4}$ ]

[Efisiensi pabrik $(\%)]=[$ Efisiensi gilingan $(\%) \mathrm{x}$ Efisiensi pengolahan $(\%) \times 10^{-2}$ ]

Sebagai contoh terapan dari formula rendemen alternatif tersebut disajikan pada Tabel 10. Rendemen dari kedua formula sama, namun demikian pada formula (b) dapat menerangkan asal mula dari pol tebu di emplasemen pabrik sehingga formula (b) dapat digunakan sebagai kontrol hasil kinerja di semua sektor dan unit produksi dalam pencapaian target rendemen, Tabel 10. Pada tabel tersebut tampak pula bahwa dengan formula (b) dapat menjelaskan bahwa rendahnya rendemen disebabkan oleh pol potensi (pol tebu di kebun) dan efisiensi tebang angkut yang rendah sehingga kualitas tebu giling (pol tebu di emplasemen) menjadi rendah. Dampaknya efisiensi pabrik menjadi rendah. Keadaan ini sesuai dengan bahasan pada Tabel 9. Sebaliknya dengan formula (a) tidak dapat menjelaskan keadaan tersebut.

Regresi dan kontribusi hasil kinerja di setiap sektor produksi terhadap rendemen dari data pada MG 1936 - 1940 dan MG 1956 - 2000 disajikan pada persamaan 2 .

Dari MG 1936 - MG 2000 terdapat perubahan rendemen sebesar 6,23 poin rendemen, Tabel 10 . Kontribusi pol tebu di kebun (pol potensi) terhadap perubahan rendemen tersebut adalah paling tinggi yaitu $63,12 \%$. Artinya bahwa perubahan rendemen yang disumbang dari pol potensi untuk pabrik gula di Jawa pada MG 1936 - 1940 dan MG 1956 - 2000 adalah sebesar 63,12\% dari perubahan rendemen. Setiap kenaikan 1 poin pol potensi menyebabkan kenaikan rendemen sebesar 0,73 poin rendemen.

Kontribusi efisiensi tebang angkut terhadap perubahan rendemen adalah sebesar 12,09\%. Artinya bahwa perubahan rendemen yang disumbang dari efisiensi tebang angkut untuk pabrik gula di Jawa pada MG 1936 - 1940 dan MG 1956 - 2000 adalah sebesar $12,09 \%$ dari perubahan rendemen. Setiap kenaikan 1 poin efisiensi tebang angkut menyebabkan kenaikan rendemen sebesar 0,09 poin.

Kontribusi efisiensi gilingan terhadap perubahan rendemen adalah sebesar 7,24\%. Artinya bahwa perubahan rendemen yang disumbang dari efisiensi gilingan untuk pabrik gula di Jawa pada MG 1936 - 1940 dan MG 1956 - 2000 adalah sebesar 7,24 \% dari perubahan rendemen. Setiap kenaikan 1 poin efisiensi gilingan menyebabkan kenaikan rendemen sebesar 0,15 poin. 
TABEL 10

POL TEBU DI KEBUN, EFISIENSI TEBANG ANGKUT, EFISIENSI PABRIK DAN RENDEMEN PADA MASA GILING (MG) 1940 (PEMBANDING), 1970 DAN 2000

\begin{tabular}{|c|c|c|c|c|}
\hline No. & Uraian & MG 1940 & MG 1970 & MG 2000 \\
\hline \multicolumn{5}{|c|}{ a. Formula Rendemen (official) } \\
\hline \multicolumn{5}{|c|}{ Sektor Tanaman: } \\
\hline 1. & Pol tebu di emplasemen, $\%$ & $14,24(a)$ & $11,37(b)$ & $8,43(\mathrm{c})$ \\
\hline \multicolumn{5}{|c|}{ Sektor Pabrik: } \\
\hline \multirow[t]{3}{*}{2.} & Efisiensi Pabrik, \% & 89,23 (a) & 79,67 (b) & $76,97(b)$ \\
\hline & - Efisiensi gilingan, \% & 94,54 (a) & $91,11(b)$ & $90,54(b)$ \\
\hline & - Efisiensi pengolahan, $\%$ & 94,34 (a) & 87,44 (b) & $85,02(b)$ \\
\hline \multicolumn{2}{|c|}{ Rendemen, \% } & $12,71(\mathrm{a})$ & $9,06(b)$ & $6,48(\mathrm{c})$ \\
\hline \multicolumn{5}{|c|}{ b. Formula rendemen alternatif (sebagai kontrol) } \\
\hline \multicolumn{5}{|c|}{ Sektor Tanaman: } \\
\hline & Pol tebu di emplasemen, $\%$ & 14,24 (a) & $11,37(b)$ & $8,43(\mathrm{c})$ \\
\hline & - Pol tebu di kebun, \% & $14,96(a)$ & $12,44(b)$ & 9,47 (c) \\
\hline & - Efisiensi Tebang Angkut, \% & $95,20(a)$ & $91,38(b)$ & $88,99(\mathrm{c})$ \\
\hline \multicolumn{5}{|c|}{ Sektor Pabrik: } \\
\hline \multirow[t]{3}{*}{2.} & Efisiensi Pabrik, \% & 89,23 (a) & $79,67(b)$ & $76,97(b)$ \\
\hline & - Efisiensi gilingan, \% & 94,54 (a) & $91,11(b)$ & $90,54(b)$ \\
\hline & - Efisiensi pengolahan, \% & 94,34 (a) & 87,44 (b) & $85,02(b)$ \\
\hline \multicolumn{2}{|c|}{ Rendemen, \% } & $12,71(a)$ & $9,06(b)$ & $6,48(\mathrm{c})$ \\
\hline
\end{tabular}

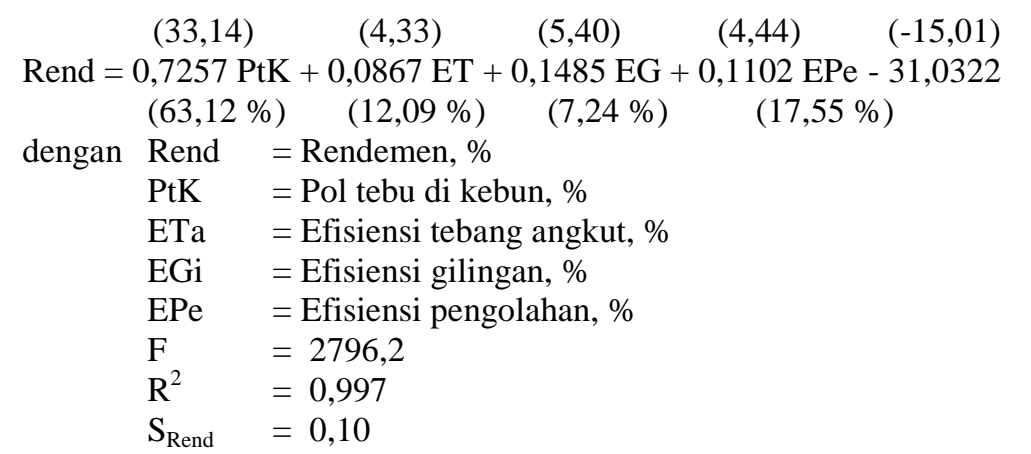

Angka dalam kurung di atas koefisien regresi $=$ t-hitung masing-masing koefisien regresi, Angka dalam kurung di bawah koefisien regresi $=$ kontribusi masing-masing komponen rendemen terhadap rendemen.

Kontribusi efisiensi pengolahan terhadap perubahan rendemen adalah sebesar $17,55 \%$. Artinya bahwa perubahan rendemen yang disumbang dari efisiensi pengolahan untuk pabrik gula di Jawa pada MG 1936 1940 dan MG 1956 - 2000 adalah sebesar 17,55 \% dari perubahan rendemen. Setiap kenaikan 1 poin efisiensi pengolahan menyebabkan kenaikan rendemen sebesar 0,11 poin.

Nilai standard (ideal) di masing-masing sektor (Tabel 11) dapat digunakan sebagai kontrol dalam pencapaian rendemen $\geq 12 \%$.

Uraian dari Tabel 1 - Tabel 10 menunjukkan betapa pentingnya nilai pol tebu di kebun, efisiensi tebang angkut dan efisiensi pabrik (gilingan dan pengolahan) untuk mengontrol kinerja masing-masing komponen produksi secara eksklusif, yaitu PTR atau Sektor Tanaman sebagai pengelola dan pemasok tebu, Sektor Pabrik sebagai penyelamat kristal yang ada dalam batang tebu untuk dijadikan GKP. Di mana PTR atau Sektor Tanaman sebagai pengelola tebu melalui proses pemilihan varietas dan pembudidayaannya didekati dengan indikator pol tebu di kebun, Sektor Tanaman atau PTR sebagai pemasok tebu melalui proses TMA didekati dengan indikator efisiensi tebang angkut, sedangkan Sektor Pabrik sebagai penyelamat kristal melalui proses pemerahan dan pengolahan didekati dengan indikator efisiensi pabrik. Sehingga di pabrik gula tidak terjadi lagi saling menuding dan melempar kesalahan antar komponen produksi dalam hal pencapaian target produksi, karena masing-masing mempunyai andil sesuai porsinya. Jika terjadi ketimpangan di salah satu atau masing-masing komponen produksi maka perlu dibenahi langsung pada komponen produksi yang paling bermasalah sehingga target produksi dapat dicapai.

Oleh karena itu disarankan untuk menentukan kadar TSAS tebu di emplasemen pabrik untuk menentukan kadar pol tebu di kebun, di samping analisa rutin yang biasa dilakukan di pabrik gula dalam kontrol pabrikasi. Kadar TSAS tebu di emplasemen pabrik = (berat TSAS dalam nira mentah + berat TSAS dalam ampas) : berat tebu $\mathrm{x} 100$. Berat TSAS $=$ berat sukrosa $+0,95$ 
x berat gula reduksi. Kadar TSAS tebu di emplasemen pabrik adalah pendekatan dari kadar pol tebu di kebun. Namun demikian, jika kadar pol tebu di kebun dapat ditentukan dengan baik (dapat melakukan sampling tebu sesuai dengan kaidah sampling, terutama sampel dapat mewakili populasi) maka kadar TSAS tebu di emplasemen pabrik tidak diperlukan lagi.

TABEL 11

NILAI STANDARD HASIL KINERJA DI SEKTRO TANAMAN DAN PABRIK

\begin{tabular}{lc}
\hline \multicolumn{1}{c}{ Komponen kontrol } & Nilai Standard \\
\hline Sektor Tanaman: & \\
\hline Pol tebu di kebun (pol potensi), \% & $\geq 15$ \\
Efisiensi tebang angkut, \% & $\geq 95$ \\
Pol tebu di emplasemen, \% & $\geq 14$ \\
\hline Sektor Pabrik: & \\
\hline Efisiensi gilingan, \% & $\geq 95$ \\
Efisiensi pengolahan, \% & $\geq 95$ \\
Rendemen, \% & $\geq 12$ \\
\hline
\end{tabular}

\section{KESIMPULAN}

Dari hasil penelitian ini dapat disimpulkan bahwa pengembangan formula rendemen untuk mengontrol kinerja pabrik gula secara menyeluruh adalah:

Rendemen $(\%)=$ Pol tebu di kebun $(\%) \times$ Efisiensi tebang angkut $(\%) \mathrm{x}$ efisiensigilingan $(\%) \mathrm{x}$ efisiensi pengolahan $(\%) \times 10^{-6}$. Nilai pol tebu di kebun sangat penting, efisiensi tebang angkut dan efisiensi pabrik (gilingan dan pengolahan) untuk mengontrol kinerja masing-masing sektor dan unit produksi tersebut dalam pencapaian target rendemen. Oleh karena itu disarankan untuk menentukan pol tebu di kebun dan efisiensi tebang angkut, di samping analisa rutin yang biasa dilakukan di pabrik gula sebagai kontrol pabrikasi, agar pabrik gula dapat membenahi sektor mana yang perlu ditingkatkan kinerjanya agar target rendemen dapat dicapai dengan baik.

\section{DAFTAR PUStaka}

[1] Anonymous. 1976, Surat Keputusan Menteri Pertanian/Ketua BP Bimas Nomor 013/SK/Mentan/BPB/3/76 tanggal 5 Maret 1976. Jakarta.

[2] Anonymous. 1984, Pedoman pelaksanaan cara Perhitungan rendemen tebu giling bagi petugas pabrik gula. BKSD. Yogyakarta.

[3] Deer, N. 1983, Classics papers of sugar cane technologist. Elseiver. p: 645.

[4] Santoso, B. E. 2009, Catatan pribadi dalam melaksanakan pelayanan dan penelitian di 54 pabrik gula di Indonesia pada musim giling 1975 - 2008. Tidak diterbitkan.

[5] Mochtar, M., Suyoto, B. E. Santoso dan A. Sudaryanto. 1997, Performance test UU. Cintamanis PTP Nusantara VII (Persero), tanggal 23 s/d 27 Agusus 1997. Laporan Teknis Intern. Pusat Penelitian Perkebunan Gula Indonesia. Pasuruan. p: 27
[6] Martoyo, T., S. Bahri, M. Saechu dan B. E. Santoso. 1999, Laporan Performance Test PG Rejoagung Baru, 2-9 Juli 1999. Laporan Teknis Intern. Pusat Penelitian Perkebunan Gula Indonesia. Pasuruan. p 15.

[7] Martoyo, T., S. . Bahri, M. Saechu dan B. E. Santoso. 1999, Laporan performance test PG Madukismo, 9-16 Agustus 1999. Laporan Teknis Intern. Pusat Penelitian Perkebunan Gula Indonesia. Pasuruan. p 25.

[8] Keer, H. W. 1970, Laboratory Manual for QueenslandSugar Mills. $5^{\text {th }}$ Ed. BSES. p 250.

[9] Meade, G. P. and Chen, J. C. P. 1977, Cane sugar handbook. $10^{\text {th }}$ Edition. John Wiley \& Sons, Singapore, New York. p: 947.

[10] Pollock, J. S., O’Hara, I. M. and Griffin, K. G. 2007, Aligning the drivers in the value chain - A new cane payment system for mackkay sugar. Proceedings of the ASSCT $29^{\text {th }}$ Confrence. Brisbane, Qld. Australia. pp: 1-8.

[11] Santoso, B. E. dan T. Martoyo. 1999, Jumlah gula sebagai sukrosa (TSAS) dalam tebu yang mengalami kerusakan untuk memprediksi potensi sukrosa di kebun. $M P G$ vol 33 (2). pp: 11-20.

[12] Marches, J. 1941, Overzicht Van Bedrijfsresultaten Beseeffendee Compagne 1940. POJ. Pasoeroean.

[13] Tjoen, T. H. dan K. H. Lhok. 1961, Ikhtisar Angka-angka Perusahaan Kampanye 1960. BP3G. Pasuruan.

[14] Tjoen, T. H. dan K. H. Lhok. 1966, Ikhtisar Angka-angka Perusahaan Kampanye 1965. BP3G. Pasuruan.

[15] Ananta, T. dan S. G. Gandana. 1971, Ikhtisar Angka-angka Perusahaan MG 1970. BP3G. Pasuruan.

[16] Ananta, T dan S. G. Gandana. 1976, Ikhtisar Angka-angka Perusahaan MG 1975. BP3G. Pasuruan.

[17] Mochtar, M., Ananta, T dan Mulyoto Hp. 1981, Ikhtisar Angka-angka Perusahaan MG 1980. BP3G. Pasuruan.

[18] Mochtar, M., T. Ananta dan S. Hadi. 1986, Ikhtisar Angkaangka Perusahaan MG 1985. Pusat Penelitian Perkebunan Gula Indonesia. Pasuruan.

[19] Mochtar, M., T. Ananta dan S. Hadi. 1991, Ikhtisar Angkaangka Perusahaan MG 1990. Pusat Penelitian Perkebunan Gula Indonesia. Pasuruan.

[20] Mochtar, M., T. Martoyo dan S. Utami. 1996, Ikhtisar Angkaangka Perusahaan MG 1995. Pusat Penelitian Perkebunan Gula Indonesia. Pasuruan.

[21] Hadi, S dan Suryanto. 2001, Ikhtisar Angka-angka Perusahaan MG 2000. Pusat Penelitian Perkebunan Gula Indonesia. Pasuruan

[22] Santoso, B.E., S. Hadisaputro dan Pujiarso. 1996, Tebu kotor dan penundaan giling: Pengaruhnya terhadap penurunan kualitas tebu dan nira. Prosiding Pertemuan Teknis. P3GI. Pasuruan. pp: TT7 1-3.

[23] Martoyo, T., S. Bahri, M. Saechu dan B. E. Santoso. 2000, Laporan hasil uji kinerja PG Krebet Baru II. Laporan Teknis Intern. P3GI. Pasuruan. p: 32.

[24] Martoyo, T., S. Bahri, M. Saechu dan B. E. Santoso. 2000, Laporan hasil uji kinerja PG Krebet Baru I. Laporan Teknis Intern. P3GI. Pasuruan. p: 33

[25] Martoyo, T., S. Bahri, M. Saechu dan B. E. Santoso. 2000, Laporan hasil uji kinerja PG Rejoagung Baru. Laporan Teknis Intern. P3GI. Pasuruan. p: 31

[26] Santoso, B. E. 2000, Pengaruh gula reduksi dan dekstran dalam analisis pol tebu. Berita P3GI No. 28. P3GI. Pasuruan. pp: 42-45.

[27] Kent, G.A., Allen, W.J., Hoare, C.P. and Dixon, T.F. 1999 The effect of extraneous matter on factory throughput and performance. Proceedings of the ASSCT $21^{\text {th }}$ Confrence. Brisbane, Qld. Australia. pp: 38-43.

[28] Pangesti, Sri. 1987, Model linier terapan I. Karunika. Jakarta. p: 421.

[29] Widasari, S. 1988, Rancangan percobaan. Karunika. Jakarta. p: 474. 